\title{
RELEVANSI KONSEP NEGARA HUKUM PANCASILA DENGAN WELFARE STATE DALAM IMPLEMENTASINYA DENGAN PELAYANAN PUBLIK DI INDONESIA
}

\author{
Oleh : \\ I Ketut Cahyadi Putra ${ }^{1}$
}

\begin{abstract}
The Pancasila Law State has an important role because its essence stems from the principle of kinship, consensus based on customary law, and human rights with the principle of balance between legal rights and obligations. Regarding the problem formulation in this research that is about elements of Pancasila Law State in relation to public service? And the relevance of the principle of Pancasila Law State with welfare state in public service in Indonesia? Type of research used in this writing is normative legal research. As contained in the Fifth Precept of Pancasila on social justice and the opening of the 1945 Constitution of the State of the Republic of Indonesia related to the phrase "to promote the general welfare" is the basic formulation of welfare state ideology then manifested into the constitution of the state Indonesia made guidance and obligation in To carry out public services in Indonesia.
\end{abstract}

Keywords: State of Law, Pancasila, Public Service

\begin{abstract}
Abstrak
Negara Hukum Pancasila memiliki peranan penting karena esensinya berpangkal pada asas kekeluargaan, musyawarah mufakat berlandaskan hukum adat, dan perlindungan hak asasi manusia dengan prinsip keseimbangan antara hak dan kewajiban dan fungsi hukum pengayoman. Mengenai rumusan masalah dalam penelitian ini yaitu tentang unsur-unsur Negara Hukum Pancasila dalam kaitan dengan pelayanan publik? Serta relevansi prinsip Negara Hukum Pancasila dengan welfare state dalam pelayanan publik di Indonesia? Jenis Penelitian yang dipakai dalam penulisan ini yaitu penelitian hukum normatif. Sebagaimana yang terkandung dalam Sila Kelima Pancasila tentang keadilan sosial dan pembukaan Undang-Undang Dasar Negara Republik Indonesia Tahun 1945 terkait frase "memajukan kesejahteraan umum" merupakan rumusan dasar ideologi welfare state kemudian diejawantahkan ke dalam batang tubuh konstitusi Negara Republik Indonesia untuk dijadikan pedoman dan kewajiban dalam melaksanakan pelayanan publik di Indonesia.
\end{abstract}

Kata kunci: Negara Hukum, Pancasila, Pelayanan Publik.

1 Program Studi Magister(S2)Ilmu Hukum, Fakultas Hukum Universitas Udayana, email: cahyadiketut@ yahoo.co.id 


\section{PENDAHULUAN}

Negara terdiri dari kumpulan individu yang mempunyai hak dan kewajiban yang saling berinteraksi untuk memenuhi kebutuhan masingmasing. Sebagai suatu organisasi yang besar, adalah wajar apabila Negara memiliki suatu pemerintah dan pemerintahan yang dibentuk dan diperlengkapi dengan kekuasaan tertinggi untuk membuat dan menjalankan peraturan-peraturan yang bersifat mengikat, demi tercapainya tujuan bersama. ${ }^{2}$

Negara merupakan alat bagi masyarakat yang mempunyai kekuasaan untuk mengatur hubunganhubungan manusia dalam masyarakat dan menertibkan gejala-gejala kekuasaan dalam masyarakat. Dari definisi ini dapat diasumsikan bahwa pemerintah merupakan personifikasi dari Negara, yang dapat bertindak atas nama Negara, yang dapat memaksakan kekuasaannya secara sah terhadap semua golongan dalam masyarakat. ${ }^{3}$

Mengenai tugas negara menurut faham modern adalah negara kesejahteraan (welfare state) artinya dalam menyelenggarakan kepentingan masyarakat untuk kemakmuran dan kesejahteraan berdasarkan keadilan dalam Negara Hukum. ${ }^{4}$

Negara yang berdasarkan atas hukum merupakan negara

2 Agung Kurniawan, 2005, Transformasi Pelayanan Publik, Pembaruan, Yogyakarta, hlm. 2.

3 Ibid.

4 Amrah Muslimin, 1985, Beberapa Asas dan Pengertian Pokok tentang Administrasi, Alumni, Bandung, hlm. 110. yang menjunjung tinggi supremasi hukum. Hukum ditempatkan sebagai acuan atau patokan tertinggi dalam penyelenggaraan negara dan pemerintahannya, yang sesuai dengan ajaran kedaulatan hukum yang menempatkan hukum sebagai sumber kedaulatan. Hal tersebut menimbulkan munculnya istilah pemerintah di bawah hukum (government under the law). ${ }^{5}$ Adapun beberapa istilah yang dikenal untuk menyebut negara hukum antara lain Rechtstaat (Belanda), Rule of Law (Inggris), Etat de Droit (Prancis), dan Stato di Doritto (Italia). ${ }^{6}$

Penegasan Negara Kesatuan Republik Indonesia sebagai negara hukum telah dinormativisasi pada Pasal 1 ayat (3) Undang-Undang Dasar Negara Republik Indonesia Tahun 1945 ( selanjutnya disingkat dengan UUD NRI 1945) yang menyatakan bahwa Negara Indonesia adalah negara hukum. Jauh sebelum itu sebelum UUD NRI Tahun 1945 diamandemen, bentuk dari negara hukum Indonesia telah dibakukan dalam penjelasan UUD NRI 1945 dengan rumusannya yaitu "Negara Indonesia adalah negara hukum(rechtsstaat)."Denganrumusan tersebut, mekanisme kehidupan berbangsa dan bernegara diatur oleh hukum (tertulis dan tidak tertulis). ${ }^{7}$

5 Munir Fuady, 2009, Teori Negara Hukum Modern (Rechtstaat), Refika Aditama, Bandung, hlm. 2.

$6 \quad$ Ibid

7 Baharudin Lopa, 1987, Permasalahan Pembinaan dan Penegakan Hukum di Indonesia, Bulan Bintang, Jakarta, h. 101. 
Seiring dengan perkembangan kenegaraan dan pemerintahan, adanya reaksi atas kegagalan negara sebagai penjaga malam (nachtwachterstaat) terjadi perkembangan dari prinsip membatasi peran negara dan pemerintahan untuk mencampuri kehidupan ekonomi dan sosial masyarakat menjadi menghendaki peran aktif negara dan pemerintahan dalam memberikan kemakmuran rakyat sehingga muncullah konsep welfare state. ${ }^{8}$

Adapun Negara Hukum yang dianut oleh Negara Indonesia adalah Negara Hukum Pancasila menunjukan bahwa ciri esensial Negara Hukum Pancasila adalah berpangkal pada asas kekeluargaan, musyawarah mufakat berlandaskan hukum adat, dan perlindungan hak asasi manusia dengan prinsip keseimbangan antara hak dan kewajiban dan fungsi hukum pengayoman. ${ }^{9}$ Hal tersebut jelas bahwa Negara Hukum di Indonesia bukan dalam artian formal tetapi dalam artian materiil yang diistilahkan negara kesejahteraan atau negara kemakmuran. Hal tersebut dirumuskan dalam Pembukaan UUD NRI 1945 dan secara operasional diformulasikan dalam Pasal 33 UUD NRI 1945. ${ }^{10}$

Sehubungan dengan kewajiban negara dalam memberikan

8 Nurmadjito, 2015, Tanya Jawab UndangUndang Pelayanan Publik, CV. Mandar Maju, Bandung, hlm. 4.

9 I Dewa Gede Atmadja, 2015, Teori Konstitusi dan Konsep Negara Hukum, Setara Press, Malang, hlm. 158.

10 Nurmadjito, op.cit, hlm. 5. kesejahteraan dan kemakmuran untuk rakyatnya, maka pemerintah melaksanakan pelayanan publik. Pelayanan publik yang professional dan berkualitas merupakan alat untuk memberikan kemakmuran yang sebesar-besarnya sesuai konsep negara welfare state sebagaimana yang tercantum dalam konstitusi Negara Republik Indonesia.

Berdasarkan latar belakang masalah yang dikemukakan di atas terdapat dua permasalahan, yaitu apa saja unsur-unsur Negara Hukum Pancasila dalam kaitan dengan pelayanan publik? Serta relevansi prinsip Negara Hukum Pancasila dengan welfare state dalam pelayanan publik di Indonesia?

Dalam Penelitian ini penulis menggunakan bahan hukum berupa peraturan perundangan-undangan dan literatur hukum terkait dengan permasalahan yang dibahas. Penulis menyadari bahwa penelitian ini terdapat persamaan dengan penelitian lainnya tetapi memiliki pembahasan yang berbeda. Adapun penelitian yang terkait dengan Relevansi Prinsip Negara Hukum Pancasila dengan Welfare state dalam implementasinya dengan Pelayanan Publik di Indonesia, antara lain :

1. Judul Penelitian: Penegakan Hukum Dalam Pelayanan Publik Di Indonesia Penulis: Indah Ayuningsih, Universitas Indonesia, Depok, Tahun 2011. Tujuan dari penelitiannya adalah 
pelaksanaan fungsi ombudsman dalam mengawasi pelayanan publik di Indonesia agar tidak terjadi penyimpangan pelayanan publik dan mal administrasi.

2. Judul Penelitian: Kebijakan Pelayanan Publik Bidang Perizinan Di Indonesia . Penulis: Nurhalisa, Universitas Sumatera Utara, Medan, Tahun 2010.

Tujuan dari penelitiannya adalah untuk mengetahui kebijakan pelayanan publik bidang perizinan dan hambatanhambatan dalam pelaksanaannya.

\section{METODE PENULISAN}

Jenis Penelitian yang digunakan dalam penelitian ini yaitu penelitian hukum normatif sedangkan jenis pendekatannya adalah pendekatan peraturan perundang-undangan dan pendekatan konseptual. Dalam penelitian hukum normatif, permasalahan dikaji berdasarkan peraturan perundang-undangan yang berlaku dan konsep/teori hukum digunakan sebagai pisau analisa untuk mencari pemecahan masalah.

\section{HASIL PEMBAHASAN}

3.1. Unsur-Unsur Negara Hukum Pancasila Dalam Kaitan Dengan Pelayanan Publik

Beberapa pandangan mengenai unsur-unsur negara hukum pancasila disampaikan oleh beberapa tokoh yakni : ${ }^{11}$

11 I Dewa Gede Atmadja, op.cit, hlm.154-158
Pertama, Oemar Senoadji. Pemikirannya bisa dilihat dalam makalahnya yang berjudul: "Indonesia Negara Hukum”. Ia menekankan perpaduan antara Indonesia dan unsurunsur negara hukum. Ia berpandangan bahwa Negara Hukum Indonesia memiliki ciri-ciri khas Indonesia. Pancasila merupakan sumber pokok hukum di Indonesia, sehingga Negara Hukum Indonesia dapat pula dinamakan sebagai Negara Hukum Pancasila. Beberapa ciri khas Negara Hukum Pancasila, yakni:

a. Hak asasi menjadi salah satu unsur terpenting negara hukum sesuai penghormatan harkat dan martabat manusia (human dinity) ditekankan pada keseimbangan perlindungan kepentingan individu dan masyarakat. Inti ciri khas hukum Indonesia tercermin dalam Hukum Adat sebagaimana dikemukakan oleh Soepomo, bahwa "struktur hukum adat" memandang bahwa kepentingan individual selaras dengan kepentingan sosial.

b. Sesuai dengan Sila Ketuhanan Yang Maha Esa, kebebasan dalam menjalankan agama dijamin oleh Konstitusi. Akan tetapi, sila ini dengan tegas menolak propaganda anti agama dan paham atheis sebagaimana di negara-negara Barat. Di Barat, kebebasan beragama (freedom of religion) konotasinya negatif, artinya, orang bebas memeluk 
kepercayaan agamanya masingmasing, tetapi bebas pula propaganda anti agama dan untuk tidak memeluk agama (atheis).

c. Dengan tidak mengabaikan hak-hak sosial, ekonomi dan kultural, yang harus diakui dan diperkembangkan dalam suatu Negara Hukum, hendaknya diperkenankan kebebasan berpikir dan berbicara (free opinion and freee press), namun harus bertanggung jawab.

d. Dalam keadaan darurat negara (staatsnoodrechts), meskipun hak-hak asasi dapat dikesampingkan, tetapi penyimpangan itu jangan sampai melebihi dari yang diperlukan untuk menghadapi keadaan luar biasa.

Kedua, Padmo Wahjono. Pemikirannya mengenai Negara Hukum Pancasila, bertolak pada asas kekeluargaan yang dirumuskan dalam Pasal 33 ayat (1) UUD NRI 1945. Asas kekeluargaan Negara Hukum Pancasila mengandung ciri-ciri : Mengutamakan kepentingan rakyat; Mengutamakan kemakmuran rakyat dan bukan kemakmuran individu; Orangperseorangan berusaha sepanjang tidak merugikan hajat hidup orang banyak; Fungsi hukum pengayoman; dan Mengakui keberadaan hukum tidak tertulis dan hukum yang tertulis.
Ketiga Philipus M. Hadjon. Pemikirannya mengenai Negara Hukum Pancasila dikemukakan dalam disertasinya yang dibukukan dengan judul "Perlindungan Hukum Bagi Rakyat" dengan merujuk asas Hukum Tata Negara Indonesia, yaitu asas demokrasi dan asas negara hukum dengan dasar negara Pancasila. Dengan demikian, dilihat dalam perspektif ajaran Yuridisme Pancasila, maka Negara Hukum Indonesia dapat disebut Negara Hukum Pancasila.

Berbagai pemikiran para Guru Besar Hukum Indonesia mengenai Negara Hukum Pancasila menunjukan bahwa ada ciri yang khas esensial bagi negara hukum yang berbeda dengan konsep Barat. Ciri esensial Negara Hukum Pancasila adalah berpangkal pada asas kekeluargaan, musyawarah mufakat berlandaskan hukum adat, dan perlindungan hak asasi manusia dengan prinsip keseimbangan antara hak dan kewajiban dan fungsi hukum pengayoman. ${ }^{12}$

Rumusan Negara Hukum Pancasila sesuai dengan unsurunsur umum Negara Hukum yakni perlindungan hak asasi manusia; peradilan bebas dan asas legalitas. Namun, kekhasan struktur masyarakat Indonesia dengan dasar negara Pancasila yang digali dari nilai-nilai yang hidup dalam masyarakat sehingga dapat diterima Negara Hukum Pancasila mengandung ciri khas yang berbeda dengan konsep Barat.

12 Ibid, hlm. 158. 
Ciri khas yang mendasar yaitu asas kekeluargaan, musyawarah mufakat, hukum tertulis yang berdampingan dengan hukum tidak tertulis sehingga tidak menafikan pluralisme hukum. ${ }^{13}$

Secara Konstitusional,

telah dirumuskan bahwa negara kesejahteraan (welfare state) merupakan tujuan negara yang dicantumkan dalam Pembukaan UUD NRI 1945 dan secara operasional diformulasikan dalam Pasal 33 UUD NRI 1945.

Dari perspektif hukum, campur tangan pemerintah dilakukan melalui mekanisme pengaturan (regeling) dan penetapan dalam bentuk perizinan (beschikking) terhadap aspek kehidupan masyarakat dalam bidang politik, sosial, budaya, pendidikan, dan bidang-bidang lainnya. ${ }^{14}$

Rumusan ideologi welfare state juga tercermin dalam Pasal 34 UUD NRI 1945 pra amandemen, dimana negara bertanggung jawab terhadap fakir miskin dan anak-anak terlantar. Pasca amandemen keempat, tugas negara dibidang kesejahteraan sosialini diperluas dengan tambahan tanggung jawab untuk mengembangkan sistem jaminan sosial dan memberdayakan kelompok masyarakat miskin, serta memberikan pelayanan kesehatan dan fasilitas pelayanan umum bagi rakyatnya.

Sebagaimana diketahui, bahwa perubahan terhadap Pasal 18 UUD

13 Ibid, hlm.159.

14 Nurmadjito, op.cit, hlm. 5.
NRI 1945 telah memberikan landasan konstitusional terhadap pelaksanaan pelayanan publik di era otonomi daerah, terutama dapat dilihat pada penambahan yang tercantum di dalam ketentuan Pasal 18A dan Pasal 18B. Pasal 18A, khususnya ayat (2) menunjukkan bahwa secara konstitusional, maka pelayanan umum merupakan hak setiap orang sebagai anggota masyarakat, dan karenanya pengaturannya di dalam UUD 1945, maka hak tersebut merupakan hak yang dapat digolongkan ke dalam jenis hak asasi, oleh karena itu pemerintah wajib menyelenggarakan pelayanan publik tersebut. Dalam hubungannya dengan pelayanan publik, sebagai realisasi keinginan ketentuan Pasal 18B, khususnya ayat (2) tersebut, pada tahun 2009 telah dibentuk Undang-Undang Nomor 25 Tahun 2009 tentang Pelayanan Publik (Lembaran Negara Republik Indonesia Tahun 2009 Nomor 112, Tambahan lembaran Negara Republik Indonesia Nomor 5038) (selanjutnya disingkat Undang-Undang Pelayanan Publik), dan Undang-Undang ini tidak hanya sebagai realisasi atas ketentuan Pasal 18B semata, tetapi juga telah memberikan rambu-rambu atau acuan penyelenggaraan pelayanan publik, dengan mengingat bahwa, bagian penjelasan UUD 1945 sudah dinyatakan tidak berlaku lagi. ${ }^{15}$

15 H. Husni Thamrin, 2013, Hukum Pelayanan Publik di Indonesia, Aswaja Pressindo, Yogyakarta, hlm. 19-20. 
Sebagaimana yang diuraikan di atas, bahwa makna yang terkandung dalam Pembukaan UUD NRI 1945 dari perspektif pelayan publik adalah mewajibkan negara memenuhi kebutuhan setiap warga negara melalui suatusystempemerintahanberdasarkan hukum yang mendukung terciptanya penyelenggaraan pelayanan umum dalam rangka memenuhi kebutuhan dasar dan hak sipil setiap warga negara atas barang publik, jasa publik, dan pelayanan administratif. Makna filosofis kewajiban negara tersebut dari perspektif pelayanan publik yaitu pembentukan negara hukum modern yang mengidentifikasi diri sebagai negara kesejahteraan. ${ }^{16}$

Terdapat lima hal yang perlu diperhatikan oleh institusi pemerintah dalam pemberian pelayanan publik yaitu:
a. Function;
b. Conformance;
c. Reliability;
d. Adanya assurance. ${ }^{17}$

Dalam memberikan standar pelayanan publik bagi masyarakat diperlukan profesionalitas dalam memberikan kepada pelayanan masyarakat. Adapun tujuan standar pelayanan yaitu:

1. Meminimalisir terjadinya kinerja pelayanan yang buruk;

2. Memberikan jaminan kepada masyarakat bahwa akan

16 Nurmadjito, op.cit, 51.

17 H. Husni Thamrin, op.cit, hlm. 32. mendapatkan

pelayanan

dalam kualitas yang dapat dipertanggungjawabkan;

3. Memberikan fokus pelayanan kepada masyarakat;

4. Menjadimediakomunikasiantara masyarakat dan penyelenggara;

5. Menjadi alat untuk mengukur kinerja pelayanan; dan

6. Menjadi alat monitoring serta evaluasi kinerja pelayanan. ${ }^{18}$

Penetapanstandarisasipelayanan sebagaimana dimaksud di atas, sesungguhnya dimaksudkan untuk menghasilkan suatu output pelayanan yang optimal. Oleh karena itu jika hakikat, asas dan standar pelayanan publik ini dikorelasikan dengan prinsip-prinsip yang terkandung dalam good governance maka tampak semakin jelas hubungan sangat intens di dalamnya. Oleh karena itu dengan menginternalisasi semua hal-hal tersebut, niscaya pelayanan publik yang berbasis good governance akan terfaktakan menjadi pelayanan publik yang berkualitas. ${ }^{19}$

\subsection{Relevansi Prinsip Negara Hukum Pancasila dengan Welfare Statedalam Pelayanan Publik di Indonesia}

Sebagaimana diamanatkan para perumus atau pendiri Negara (the founding fathers) Negara Kesatuan Republik Indonesia adalah Negara

18 Nurmadjito, op.cit, hlm. 77.

19 H. Husni Thamrin, op.cit, hlm. 61. 
kesejahteraan yang dicantumkan dalam pembukaan UUD NRI 1945, khususnya pada alinea ke IV dan secara operasional diformulasikan dalam Pasal 33 UUD NRI 1945. ${ }^{20}$

\section{Ciri-ciri} dari

Negara kesejahteraan yaitu munculnya campur tangan pemerintah terhadap aspek kehidupan masyarakat dan dalam melaksanakan fungsi pemerintahan, pemerintah seringkali melakukan intervensi terhadap berbagai aspek kehidupan masyarakat guna menciptakan kesejahteraan masyarakat. $^{21}$

Sejarah mencatat bahwa pidato Soekarno tanggal 1 Juni 1945, memang beliau langsung menyoroti masalah dasar negara sebagaimana yang diminta oleh Ketua Radjiman. Dalam pernyataan beliau mengatakan: “...... menurut anggapan saya diminta oleh paduka tuan ketua yang mulia bahwa Philosofisce groundslag itulah filsafat fundamental, jiwa dalam mendirikan Indonesia yang merdeka...."22.

Untuk itu Soekarno mengajukan lima prinsip Philosofisce groundslag bagi Indonesia yaitu :

1. Kebangsaan Indonesia

2. Internasional atau Perikemanusiaan

3. Mufakat atau Demokrasi

4. Kesejahteraan Sosial

5. Ketuhanan yang berbudaya. ${ }^{23}$

20 Nurmadjito, op.cit, hlm. 5

21 Ibid.

22 Dahlan Thaib dkk, 1999, Teori dan Hukum Konstitusi, PT. Raja Grafindo Persada, Jakarta,hlm. 96.

23 Ibid.
Menurut Soekarno lima prinsip tersebut bukanlah Panca Dharma, tetapi Pancasila sebagaimana atas petunjuk dari ahli bahasa. ${ }^{24}$

Setelah melalui berbagai proses akhirnya pada tanggal 18 Agustus 1945 disahkannya UUD NRI 1945 yang tersusun sebagai berikut: pertama, Pembukaan (Preambule) kedua, batang tubuh (the body of the constitusion), ketiga, bagian penutup, aturan peralihan dan aturan tambahan.

Apabila ditelaah terkait sistematika dalam UUD NRI 1945, gagasan negara kesejahteraan tercermin dalam Bab XIV tentang kesejahteraan sosial. Apabila dikonstruksikan bahwa Pancasila sebagai philosophische groundslag maka berarti Pancasila berkedudukan sebagai Filsafat Dasar Negara, "direfleksikan" ke dalam Pembukaan UUD atau Norma Fundamental Negara (StaatsfundamentalNorm), selanjutnya norma-norma dalam Pembukaan tersebut dijabarkan ke dalam PasalPasal UUD (Grund Norm). ${ }^{25}$

Pemikiran mengenai negara kesejahteraan dalam konsep negara hukum Pancasila, sejalan dengan pemikiran Padmo Wahjono. Pemikirannya mengenai Negara Hukum Pancasila, bertolak pada asas kekeluargaan sebagaimana terkandung dalam Pasal 33 UUD NRI 1945 ayat (1). ${ }^{26}$

\footnotetext{
24 Ibid, hlm. 97.

25 Ibid.

26 I Dewa Gede Atmadja, op.cit, hlm. 157.
} 
Dalam pemikiran tersebut jika di telaah, maka salah satu ciri dari asas kekeluargaan adalah Mengutamakan kemakmuran rakyat dan kemakmuran individu sejalan dengan ketentuan dalam Pasal 33 ayat (2) dan (3) UUD NRI 1945. Dalam konteks ini maka Indonesia sebagai Negara Hukum Pancasila juga melaksanakan konsepkonsep welfare state yang salah satu tujuannya menyejahterakan rakyat dan pelayanan publik merupakan salah satu instrumen bagi pemerintah dalam mewujudkan Negara Hukum Modern yaitu konsep Negara Kesejahteraan (welfare state).

Konsep Negara Kesejahteraan menempatkan bestuurszorg functie sebagai fungsi yang pertama bagi negara. Fungsi zorgen membebankan kepada Negara untuk memberikan pelayanan yang sebaik-baiknya dan seluas-luasnya kepada masyarakat, sehingga semua lapisan masyarakat dapat menikmati kesejahteraan dalam kehidupannya. ${ }^{27}$

Pelayanan publik di Indonesia, dalam bidang Pendidikan merupakan salah satu bentuk pelayanan pemerintah dalam mewujudkan kesejahteraan. Sejak diundangkannya UndangUndang Nomor 20 Tahun 2003 tentang Sistem Pendidikan Nasional, Pemerintah dan Pemerintah Daerah menjamin wajib belajar secara gratis pada tingkat pendidikan dasar yaitu Sekolah Dasar dan Sekolah Menengah Pertama. Selain di bidang Pendidikan

27 Nurmadjito, op.cit, hlm. 4. pemerintahjugamemberikanpelayanan kesehatan yang baru dijalankan pada tahun 2008 melalui program Jaminan Kesehatan masyarakat.

Sejalan dengan pemikiran Philipus M. Hadjon. Pemikirannya mengenai Negara Hukum Pancasila dikemukakan dalam disertasinya yang dibukukan dengan judul "Perlindungan Hukum Bagi Rakyat" dengan merujuk asas Hukum Tata Negara Indonesia, yaitu asas demokrasi dan asas negara hukum dengan dasar negara Pancasila. Dengan demikian, dari perspektif Yuridisme Pancasila, maka Negara Hukum Indonesia dapat disebut Negara Hukum Pancasila dengan ciri-ciri: adanya kerukunan antara rakyat dan pemerintah. Asas kerukunan adalah perwujudan dari jiwa dan spirit kebangsaan Indonesia yang dibangun diatas kebersamaan (komunalisme) bukan individualisme, yang menonjolkan budaya gotong royong dan kekeluargaan diantara elemen kebangsaan, sehingga yang hendak dicapai dari adanya demokrasi dan negara berdasar hukum adalah keserasian/ keseimbangan hubungan antara rakyat dengan pemerintah. ${ }^{28}$

Terdapat empat dimensi dalam pelayanan publik, yaitu dimensi politik, dimensi ekonomi, dimensi sosial budaya dan dimensi hukum.

Dimensi politik mencakup kebijakan politik negara sebagaimana dimaksudkan dalam Pembukaan UUD NRI 1945, Pasal 33 dan Pasal 34

28 I Dewa Gede Atmadja, op.cit, hlm.157. 
UUD NRI 1945. Ketentuan konstitusi menunjukkan bahwa dari sisi politik, pelayanan pemerintah merupakan salah satu alasan sekaligus tujuan dibentuknya negara. Pilihan pendiri Negara dan Bangsa Indonesia menuju negara kesejahteraan, mengandung konsekuensi terwujudnya pelayanan kepada masyarakat. Pelayanan publik merupakan refleksi dari pelaksanaan peran negara melayani warga negara berdasarkan keinginan dalam membentuk negara. Peran negara dalam pelayanan publik dilaksanakan oleh suatu pemerintahan yang dijalankan kekuatan politik yang berkuasa (the rulling party). Sehingga parameter aspiratif ada atau tidaknya kekuatan politik dalam meraih dukungan masyarakat disandarkan pada komitmen dan pelaksanaan komitmen kekuatan politik dalam penyelenggaraan pelayanan publik.

Dimensi ekonomi menunjukkan bahwa pelayanan adalah aspek ekonomi yang mewajibkan pemerintah menyediakan atau mengadakan barang dan jasa yang diperlukan warga negara sebagai konsumen. Negara menyediakan pelayanan karena kedudukan menjadi satu-satunya penyedia barang dan jasa publik, yang dapat dimaknai bahwa kedudukan negara bersifat monopolitis. Dalam artian lain pelayanan merupakan komoditas dasar untuk menggerakkan perekonomian yang mampu menumbuhkankepercayaanataskinerja pemerintah. Komoditas pelayanan publik seperti: jasa transportasi, kesehatan, pendidikan, penyediaan pangan, listrik, air dan administrasi pemerintahan serta barang kebutuhan pokok merupakan barang dan jasa yang memiliki multiplier effect yang tinggi.

$\begin{array}{ccr}\text { Dimensi } & \text { sosial } & \begin{array}{r}\text { budaya } \\ \text { menunjukkan }\end{array}\end{array}$ publik merupakan sarana pemenuhan kebutuhan dasar warga negara demi mencapai kesejahteraan sosial. Pelayanan tidak hanya penting dari segi kualitas material, seperti ketepatan waktu, melainkan juga tingkat penyesuaian penyelenggara pelayanan dengan sistem sosial budaya yang berlangsung di tempat melakukan pelayanan. Aspek yang dipuaskan bukan hanya lahir, termasuk batin masyarakat, sehingga masyarakat semakin memberikan kepercayaan yang tulus kepada pemerintah.

Dimensi hukum menunjukkan bahwakewajiban negara melaksanakan pelayanan adalah atas dasar hukum yang berlaku dan begitu pula hak warga negara memperoleh pelayanan dilandasi atas hukum. Dalam artian pelayanan merupakan hak rakyat untuk memperolehnya, baik dalam rangka mendapatkan hak-haknya maupun dalam memenuhi kewajiban sebagai warga negara. Dari sisi penyelenggara pelayanan, dapat disebutkan sebagai kewajiban dan tanggung jawab (responsibility), yang didefinisikan sebagai kemampuan untuk menjawab atau memenuhi janji atau commitment 
saat melakukan kampanye pemilihan umum pemenang partai dalam pesta demokrasi. Oleh karena itu, sasaran negara adalah kepercayaan sebagai output, artinya publik percaya karena terbukti hasilnya, bukan sekedar janji. ${ }^{29}$

Agar pelayanan publik dapat berjalan dengan baik maka perlu dilakukan Pengawasan atas penyelenggaraan pelayanan publik sebagaimana diatur dalam Pasal 35 Undang-Undang Pelayanan Publik yang dilakukan oleh: (a) pengawas internal; dan (b) pengawas eksternal. Pengawasan internal dilakukan oleh atasan langsung dan pengawas fungsional. Pengawas eksternal dilakukan oleh masyarakat, Ombudsman dan Dewan Perwakilan Rakyat di tingkat nasional atau daerah. ${ }^{30}$

Pengaturan pengawasan Undang-Undang Pelayanan Publik dimaknai sebagai transformasi dari perkembangan dinamika masyarakat yang menghendaki penyelenggaraan kepemerintahan berdasarkan akuntabilitas dan transparan. Tuntutan atas keterbukaan penyelenggaraan manajemen pemerintah semakin meningkat dan terfokus menilai dan mengawasi kinerja pemerintahan. Respon atas dinamika tersebut diwujudkan dalam model pengawasan yang dibangun dalam Undang-Undang Pelayanan Publik. ${ }^{31}$

29 Nurmadjito, op.cit, hlm. 10-11.

30 Nurmadjito, op.cit, hlm. 102.

31 Ibid, hlm. 102.

\section{KESIMPULAN}

1. Unsur-Unsur Negara Hukum Pancasila Dalam Kaitan Dengan Pelayanan Publik adalah berpangkal pada asas kekeluargaan, musyawarah mufakat berlandaskan hukum adat, dan perlindungan hak asasi manusia dengan prinsip keseimbangan antara hak dan kewajiban dan fungsi hukum pengayoman. Dari unsur-unsur tersebut negara berkewajiban melaksanakan pelayanan dalam kerangka pengelolaan kepemerintahan dan kesadaran berpolitik dalam membangun kesejahteraan rakyat.

2. Relevansi Prinsip Negara Hukum Pancasila dengan Welfare State dalam Pelayanan Publik di Indonesia adalah Indonesia sebagai negara yang menganut konsep negara hukum Pancasila berupaya mengutamakan kesejahteraan rakyat dimana dalam mewujudkan kesejahteraan tersebut, pemerintah wajib memberikan pelayanan publik sesuai dengan prinsip-prinsip negara hukum Pancasila. Hal ini secara jelas dirumuskan dalam Pembukaan UUD NRI 1945 alinea IV terkait frase "memajukan kesejahteraan umum" dan secara operasional diformulasikan dalam Pasal 33 UUD NRI 1945 dan UndangUndang Pelayanan Publik. 


\section{DAFTAR PUSTAKA}

\section{Buku}

Atmadja, I Dewa Gede, 2015, Teori Konstitusi dan Konsep Negara Hukum, Setara Press, Malang.

Fuady, Munir, 2009, Teori Negara

Hukum Modern (Rechtstaat), Refika Aditama, Bandung.

Kurniawan,Agung,2005,Transformasi Pelayanan Publik, Pembaruan, Yogyakarta.

Lopa, Baharudin, 1987, Permasalahan

Pembinaan dan Penegakan

Hukum di Indonesia, Bulan Bintang, Jakarta.

Muslimin, Amrah, 1985, Beberapa Asas dan Pengertian Pokok tentang Administrasi, Alumni, Bandung.

Nurmadjito, 2015, Tanya Jawab Undang-Undang Pelayanan Publik, CV. Mandar Maju, Bandung.

Thaib, Dahlan, dkk, 1999, Teori dan Hukum Konstitusi, PT. Raja Grafindo Persada, Jakarta.

Thamrin, H. Husni, 2013, Hukum Pelayanan Publik di Indonesia, Aswaja Pressindo, Yogyakarta.

\section{Peraturan}

\section{Perundang-undangan}

$\begin{array}{ccc}\begin{array}{c}\text { Undang-Undang } \\ \text { Republik } \\ 1945 .\end{array} & \begin{array}{c}\text { Dasar } \\ \text { Indonesia }\end{array} & \begin{array}{r}\text { Negara } \\ \text { Tahun }\end{array} \\ \text { Undang-Undang } & \text { Nomor } 25 & \text { Tahun } \\ 2009 \text { tentang Pelayanan } & \text { Publik }\end{array}$

(Lembaran Negara Republik Indonesia Tahun 2009 Nomor 112, Tambahan Lembaran Negara Republik Indonesia Nomor 5038).

Undang-Undang Nomor 20 Tahun 2003 tentang Sistem Pendidikan Nasional (Lembaran Negara Republik Indonesia Tahun 2003 Nomor 78, Tambahan Lembaran Negara Republik Indonesia Nomor 4301). 